\title{
Acyclovir in first attacks of genital herpes and prevention of recurrences
}

\author{
A MINDEL.* I V D WELLER.*A FAHERTY.* S SUTHERLAND, † A P FIDDIAN,* AND M W ADLER* \\ From the *Academic Department of Genitourinary Medicine and the $\dagger$ Department of Virology, Middlesex Hospital \\ Medical School, London
}

SUMMARY Sixty women patients experiencing a first attack of genital herpes were randomly treated with either oral acyclovir for 42 days or oral acyclovir for five days followed by placebo for 37 days. The median time to the first recurrence in patients receiving acyclovir for 42 days was 66.5 days compared with 24 days in those who received acyclovir for only five days $(p<0.0001)$. This significant difference, however, was only observed for the treatment period. The frequency of recurrences was also reduced during the period of treatment in those who received prolonged treatment. During the subsequent follow up period, however, patients in both groups had a similar frequency of recurrences. Patients with infections due to herpes simplex virus type I (HSV I) had a significantly longer time to the first recurrence $(p<0.001)$ and fewer recurrences $(p<0.001)$ than those infected with HSV II, irrespective of treatment.

\section{Introduction}

Short courses of acyclovir have been shown to hasten healing and reduce the duration of symptoms and viral shedding in patients experiencing a first attack of genital herpes. ${ }^{-1-9}$ The drug does not, however, appear to decrease the likelihood of recurrences, ${ }^{24-6}{ }^{10}$ and in one study over half the patients suffered at least one recurrence within three months after the first episode. ${ }^{10}$ Recurrences are the most troublesome aspect of genital herpes and constitute a reservoir of infection in the community. ${ }^{11}$

It has been suggested that prolonged treatment of the first attack with acyclovir may decrease the frequency of recurrences. ${ }^{3}$ We therefore decided to compare the recommended five day course with a prolonged course of acyclovir in patients experiencing a first attack of genital herpes to see if a prolonged course could reduce the likelihood of recurrences and confer any additional benefit during the first attack.

\section{Patients and methods}

SELECTION, TREATMENT, AND CLINICAL EVALUATION OF PATIENTS

Women patients attending the genitourinary clinic of

Address for reprints: Dr A Mindel, James Pringle House, Middlesex Hospital, London WIN 8AA

Accepted for publication 21 July 1985 this hospital within five days of a first attack of genital herpes were offered the opportunity of participating in the study. We limited the study to women patients as they usually have more severe infections. ${ }^{12}$ Exclusion criteria were identical to those used in a previous study. ${ }^{1}$ Informed consent was obtained from all patients.

We randomised patients into two treatment groups. Those in treatment group 1 received a prolonged course of acyclovir (200 mg five times a day for five days followed by acyclovir $200 \mathrm{mg}$ four times a day for 37 days) and those in group 2 received a short course of acyclovir (200 mg five times a day for five days followed by placebo $200 \mathrm{mg}$ four times a day for 37 days). The total duration of treatment in both groups was therefore 42 days.

The clinical status of each patient was assessed at entry, daily during the first seven days (excluding weekends), and twice weekly during the following six weeks. Thereafter patients attended monthly for at least six months and were also asked to attend if they suffered a recurrence. We examined and took a history of patients at each visit, and recorded the results on a standardised recording schedule.

At each visit we took swabs for viral culture, which were handled as described previously. Isolates were typed using either restriction endonuclease analysis ${ }^{13}$ or an immunofluorescence test using monoclonal antibodies. ${ }^{14}$ 
ANALYSIS OF RESULTS

We compared demographic characteristics and the frequency of recurrences either by the $\chi^{2}$ or the MannWhitney test and assessed differences between groups in healing time, duration of symptoms, duration of viral shedding, and the time to first recurrence using a $\log$ rank test.

\section{Results}

\section{PATIENT CHARACTERISTICS}

Table I shows the demographic details of the 60 patients in the study. Half (group 1) received long term, and half (group 2) a short course of treatment with acyclovir. At presentation there were no appreciable differences between the two treatment groups in age or duration and severity of signs and symptoms. Viral isolates were typed in 55 of the 60 patients. Of the $55,41(75 \%)$ were infected with HSV II and $14(25 \%) \mathrm{HSV}$ I. The distribution of viral types was similar in the two treatment groups. All but one of the patients were followed up for at least six months; the exception was a patient receiving a short course of treatment, who was lost to follow up after 37 days. The median duration of follow up was 317 days in patients in group 1 and 297 days in patients in group 2. This difference was not significant.

HEALING TIME OF FIRST ATTACK, DURATION OF VIRAL SHEDDING, AND SYMPTOMS

Table II shows that the patients in the two treatment groups did not differ significantly in healing times, duration of viral shedding, or duration of local or systemic symptoms. Individual symptoms, which included pain, itching, dysuria, discharge, fever, headache, and malaise, were also compared and differences between the two groups were not significant.

TIME TO FIRST RECURRENCE AND FREQUENCY OF RECURRENCES

Figure 1 shows that the median time to the first recurrence in group 1 patients was 66.5 days compared with 24 days in group 2 patients. The difference was significant $(p<0.001)$ for the 42 day treatment period but not for the full duration of follow up.

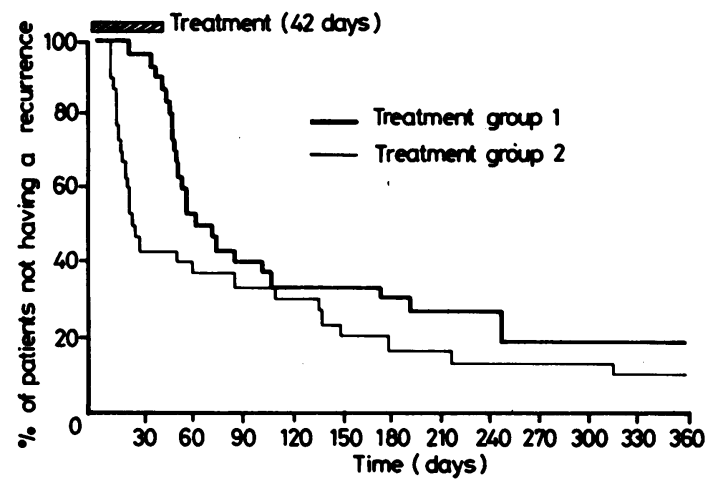

FIG I Time to first recurrence comparing patients receiving acyclovir for 42 days (group 1) or five days (group 2).

TABLE I Demographic details of 60 women experiencing first attacks of genital herpes and receiving acyclovir for 42 days (group 1 ) or 5 days (group 2)

Treatment groups:

\begin{tabular}{cc}
\hline $1(n=30)$ & $2(n=30)$ \\
\hline $24 \cdot 3(5 \cdot 7)$ & $25 \cdot 2(7 \cdot 0)$ \\
$4 \cdot 0(1 \cdot 6)$ & $4 \cdot 1(1 \cdot 6)$ \\
$2 \cdot 7(1 \cdot 2)$ & $3 \cdot 0(1 \cdot 4)$ \\
6 & 7 \\
6 & 7 \\
8 & 9 \\
9 & 5 \\
18 & 23 \\
3 & 2
\end{tabular}

TABLE II Duration of symptoms, time to healing, and duration of viral shedding in patients receiving acyclovir for 42 days (group l) or 5 days (group 2)

\begin{tabular}{|c|c|c|c|c|c|}
\hline & \multicolumn{2}{|c|}{ Treatment group l } & \multicolumn{2}{|c|}{ Treatment group 2} & Difference \\
\hline $\begin{array}{l}\text { Local symptoms } \\
\text { Systemic symptoms } \\
\text { Healing } \\
\text { Viral shedding }\end{array}$ & $\begin{array}{l}30 \\
21 \\
30 \\
29\end{array}$ & $\begin{array}{r}11(1-31) \\
4(2-24) \\
11(5-34) \\
3(1-8)\end{array}$ & $\begin{array}{l}30 \\
25 \\
30 \\
29\end{array}$ & $\begin{array}{r}11(2-28) \\
5(1-31) \\
11(5-32) \\
4(1-10)\end{array}$ & $\begin{array}{l}\text { NS } \\
\text { NS } \\
\text { NS } \\
\text { NS }\end{array}$ \\
\hline
\end{tabular}


TABLE III Frequency of recurrence a month comparing patients receiving acyclovir for 42 days (group 1) or 5 days (group 2)

\begin{tabular}{|c|c|c|c|c|c|}
\hline \multirow{2}{*}{$\begin{array}{l}\text { Follow up } \\
\text { period } \\
\text { (days) }\end{array}$} & \multicolumn{2}{|c|}{ Treatment group 1} & \multicolumn{2}{|c|}{ Treatment group 2} & \multirow[b]{2}{*}{ Difference } \\
\hline & $\begin{array}{l}\text { No with } \\
\text { recurrences/ } \\
\text { No followed up }\end{array}$ & $\begin{array}{l}\text { Mean }(S D) \\
\text { recurrences/ } \\
a \text { month }\end{array}$ & $\begin{array}{l}\text { No with } \\
\text { recurrences/ } \\
\text { No followed up }\end{array}$ & $\begin{array}{l}\text { Mean }(S D) \\
\text { recurrences/ } \\
a \text { month }\end{array}$ & \\
\hline $\begin{array}{l}0-42 \\
0-90 \\
0-180 \\
0-270 \\
0-360\end{array}$ & $\begin{array}{r}4 / 30 \\
18 / 30 \\
21 / 30 \\
18 / 20 \\
12 / 12\end{array}$ & $\begin{array}{l}0.12(0.4) \\
0.43(0.6) \\
0.42(0.6) \\
0.45(0.6) \\
0.42(0.5)\end{array}$ & $\begin{array}{c}16 / 29 \\
19 / 29 \\
24 / 29 \\
13 / 17 \\
7 / 9\end{array}$ & $\begin{array}{l}0.76(1.2) \\
0.60(0.9) \\
0.46(0.6) \\
0.30(0.4) \\
0.22(0.3)\end{array}$ & $\begin{array}{l}p=0.0004 \\
\text { NS } \\
\text { NS } \\
\text { NS } \\
\text { NS }\end{array}$ \\
\hline
\end{tabular}

TABLE IV Frequency of recurrence comparing patients infected with herpes simplex virus type I or II

\begin{tabular}{|c|c|c|c|c|c|c|}
\hline \multirow{2}{*}{$\begin{array}{l}\text { Follow up } \\
\text { period } \\
\text { (days) }\end{array}$} & \multicolumn{3}{|c|}{ Patients infected with $\mathrm{HSV} I$} & \multicolumn{2}{|c|}{ Patients infected with HSV II } & \multirow[b]{2}{*}{ Difference } \\
\hline & $\begin{array}{l}\text { No with } \\
\text { recurrences/ } \\
\text { No followed up }\end{array}$ & $\begin{array}{l}\text { Mean } \\
\text { recur } \\
a \mathrm{~m}\end{array}$ & & $\begin{array}{l}\text { No with } \\
\text { recurrences/ } \\
\text { No followed up }\end{array}$ & $\begin{array}{l}\text { Mean } S D \\
\text { recurrences/ } \\
a \text { month }\end{array}$ & \\
\hline $\begin{array}{l}0-42 \\
0-90 \\
0-180 \\
0-270 \\
0-360\end{array}$ & $\begin{array}{l}0 / 14 \\
1 / 14 \\
5 / 14 \\
6 / 9 \\
3 / 4\end{array}$ & $\begin{array}{l}0 \\
0.02 \\
0.07 \\
0.10 \\
0.10\end{array}$ & $\begin{array}{l}(0) \\
(0.1) \\
(0.1) \\
(0.1) \\
(0.2)\end{array}$ & $\begin{array}{l}19 / 40 \\
34 / 40 \\
38 / 40 \\
25 / 26 \\
16 / 16\end{array}$ & $\begin{array}{l}0.61(1.0) \\
0.72(0.9) \\
0.60(0.7) \\
0.51(0.6) \\
0.41(0.5)\end{array}$ & $\begin{array}{l}p=0.002 \\
p 0.0001 \\
p 0.0001 \\
p=0.0001 \\
p=0.013\end{array}$ \\
\hline
\end{tabular}

Table III shows that during the first 42 days (the duration of treatment) patients in treatment group 1 had significantly fewer recurrences $(0 \cdot 12$ a month) than those in group $2(0.76$ a month $)(p=0.0004)$. During subsequent follow up, however, the frequency of recurrences was not significantly different between the two treatment groups.

In contrast, the median time to the first recurrence was significantly longer and recurrences significantly less frequent in patients infected with HSV type I than in those infected with HSV type II, irrespective of their treatment. Figure 2 shows that the median time to the first recurrence in patients with HSV 1 was 193 days compared with 44 days in patients with HSV II $(p<0.001)$. Table IV shows the frequency of recurrences comparing patients by type of infection.

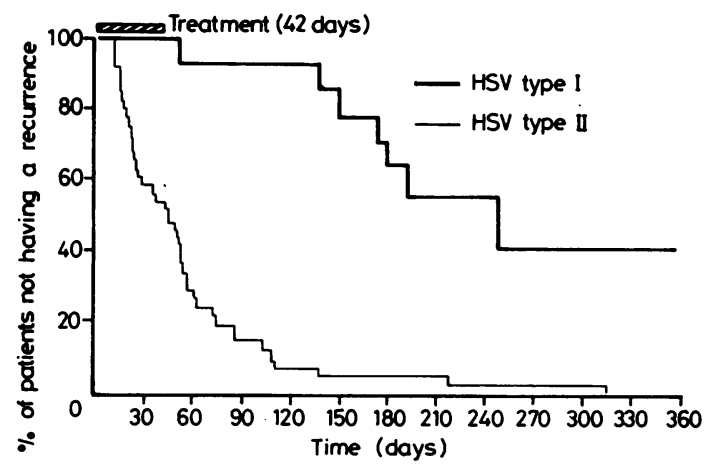

FIG 2 Time to the first recurrence comparing patients infected with herpes simplex virus (HSV) types I or II.
At each follow up visit patients with HSV I infection had significantly fewer recurrences than those with HSV II. For example, by day 180 patients infected with HSV I had had 0.07 recurrences a month compared with 0.6 a month in those with HSV II $(\mathrm{p} .<0.0001)$.

\section{COMPLIANCE WITH TREATMENT AND SIDE EFFECTS}

The two groups were similar in compliance with treatment. In group 1 patients the mean number of missed tablets was 4.2 compared with 4.3 in group 2 patients, which was not a significant difference.

Several patients had complaints that they thought might be associated with treatment. In group 1 patients these included slight constipation (experienced by two) and transient nausea (one), and in group 2 patients transient diarrhoea (three), nausea (one), increase in appetite (one), Bell's palsy (one). A few patients were noted to have biochemical or haematological abnormalities. One group 1 patient had a marginal and transient decrease in the total white cell count. One group 2 patient had an increase serum aspartate transaminase activity and one raised serum urea concentration, but in both the increases were slight and short lived. Seven patients had raised plasma bilirubin concentrations. In two patients (one in each group) this rise was persistent (before, during, and after treatment), whereas in the remaining five (two in group 1 and three in group 2) the rise was slight and only noted on a single occasion.

None of the symptoms or biochemical or haematological abnormalities were thought to be due to treatment. 
Discussion

This study shows that prölonged treatment with oral acyclovir of patients experiencing a first attack of genital herpes confers little benefit over the recommended five day treatment. Indeed the duration of symptoms, the time to healing, and the duration of viral shedding were virtually identical in patients who received five days of active treatment and those who received 42 days. Several other trials with short courses of oral acyclovir in first attacks of genital herpes have shown similar durations of these variables. ${ }^{3-5}$

The time to the first recurrence was, however, significantly longer in patients who received the 42 day course of acyclovir compared with those who received five days of active treatment. While patients take acyclovir there seem to be no recurrences, but as soon as treatment stops the recurrences begin, and the frequency of recurrences in the two groups then becomes virtually identical. This is not surprising and is similar to results after treating prophylactically with acyclovir patients who had recurrent genital herpes; recurrences ceased, but started again after the drug was stopped. ${ }^{15-17}$

One of the most interesting points to emerge from this study is the observation that patients with HSV I infection have a significantly longer time to their first recurrence and far less frequent recurrences than those with HSV II infections. Some patients infected with HSV I will probably never have a recurrence. This difference in recurrence rates between the two viral types has been shown in several previous studies. ${ }^{1018}$ The fact that the two viral types differ so enormously in their natural history will have an impact not only on the conduct of future clinical trials but also on the management and counselling of patients. Some patients infected with HSV II who have frequent recurrences may require prophylactic treatment with oral acyclovir. ${ }^{15-17}$ It is not clear why these two similar viruses show such a difference in their ability to produce recurrences. There are several possible explanations. Perhaps this difference reflects a relative inability of HSV I to become latent. The two viruses do differ in their interaction with neuronal tissue. For example, experiments in mice have shown that HSV II is more neurovirulent than HSV I, and HSV I is usually isolated from patients with herpes encephalitis, whereas HSV II is the commonest cause of herpes meningitis. ${ }^{1920}$ Receptor sites for HSV I and HSV II may differ with different neuronal tissue, and the sacral ganglia may have a relative lack of HSV I receptor sites. Another possible explanation is that, having become latent in the sacral ganglia, the HSV I virus has "difficulty" in reactivating. This may reflect an intrinsic property of the virus itself or may be the result of specific immune defence mechanisms of the host.
This trial has shown that the first attack of genital herpes can be successfully treated with a short course of oral acyclovir, that the only benefit in continuing treatment after five days is to delay the onset of recurrences, and that prolonged treatment does not appear to affect the subsequent recurrence rate. Finally, we have highlighted the difference in recurrence rate between patients with HSV I and those with HSV II infections.

We thank the medical laboratory scientific officers in the virology department for virus isolation, Mr D Hindley and Mr P Williams for statistical help, and the doctors and nurses at James Pringle House for help in recruiting patients. IVDW is a Wellcome Trust Senior Lecturer in Infectious Diseases. Infectious Diseases.

\section{References}

1. Mindel A, Adler MW, Sutherland S, Fiddian AP. Intravenous acyclovir treatment for primary genital herpes. Lancet 1982;i:697-700.

2. Corey L, Fife KH, Benedetti JK, et cal. Intravenous acyclovir for the treatment of primary genital herpes. Ann Intern Med 1983;98:914-21.

3. Nilson AE, Aasen T, Halsos AM, et al. Efficacy of oral acyclovir in the treatment of initial and recurrent genital herpes. Lancet 1982;ii:571-73.

4. Bryson $\mathrm{YJ}$, Dillon $\mathrm{M}$, Lovett $\mathrm{M}$, et al. Treatment of first episodes of genital herpes simplex virus infection with oral acyclovir, $N$ Engl J Med 1983:308:916-20.

5. Mertz GJ, Critchlow CW, Benedetti J, et al. Double blind pacebo controlled trial of oral acyclovir in first episode genital herpes simplex virus infection. JAMA 1984;252:1147-51.

6. Corey L, Nahmias AJ, Guinan ME, Benedetti JK, Critchlow CW, Holmes KK. A trial of topical acyclovir in genital herpes simplex virus infection. $N$ Engl J Med 1982;306:1313-9.

7. Thin RN, Nabarro JM, Parker JD, Fiddian AP. Topical acyclovir in the treatment of initial genital herpes. British Journal of Venereal Diseases 1983;59:116-9.

8. Fiddian AP, Kinghorn GR, Goldmeier D, et al. Topical acyclovir in the treatment of genital herpes: a comparison with systemic therapy. J Antimicrob Chemother 1983;12 suppl B:6777 .

9. Kinghorn GR, Turner EB, Barton IG, Potter CW, Burke CA, Fiddian AP. Efficacy of topical acyclovir cream in first and recurrent episodes of genital herpes. Antiviral Res 1983;3:291301

10. iminael A, Sutneriana $S$. Uentrat nerpes: tne alsease and its treatment including intravenous acyclovir. $J$ Antimicrob Chemother 1983;12 suppl B:51-9.

11. Corey $\mathrm{L}$. The diagnosis and treatment of genital herpes. JAMA 1982;248: 1041-9.

12. Corey L, Adams HG, Brown ZA, Holmes KK. Genital herpes simplex virus infections: clinical manifestations, course and complications. Ann Intern Med 1983;98:958-72.

13. Chan WL. Protective immunisation of mice with specific HSV I glycoproteins. Immunology 1983;49:343-52.

14. Lonsdale DM. A rapid technique for distinguishing herpessimplex virus type I from type II by restriction enzyme technology. Lancet 1979;i:849-57.

15. Mindel A, Weller IVD, Faherty A, et al. Prophylactic oral acyclovir in recurrent genital herpes. Lancet 1984;ii:57-9.

16. Douglas JM, Critchlow C, Benedetti J. A double blind study of oral acyclovir for suppression of recurrences of genital herpes virus infection. $N$ Engl J Med 1984;310:1551-6. 
17. Strauss SE, Takiff HE, Seidlin, $M$ et al. Suppression of frequently recurring genital herpes: a placebo controlled double-blind trial of oral acyclovir. $N$ Engl $J$ Med 1984;310:1545-50

18. Reeves WC, Corey L, Adams HG, Vontver LA, Holmes KK. Risk of recurrence after first episode of genital herpes. Relation to HSV type and antibody response. N Engl JMed 1981;305:315-
19. McKendall RR. Comparative neurovirulence and latency of HSV I and HSV 2 following footpad inoculation in mice.JMed Virol 1980;5:25-32.

20. Nahmias AJ, Roizman B. Infection with herpes simplex viruses 1 and 2. N Engl J Med 1973;289:781-9. 